Article

\title{
CuInTe 2 Nanocrystals: Shape and Size Control, Formation Mechanism and Application, and Use as Photovoltaics
}

\author{
Guanwei Jia ${ }^{1,2}{ }^{\oplus}$, Baokun Liu ${ }^{1}$, Kun Wang ${ }^{1}$, Chengduo Wang ${ }^{1}$, Peixu Yang ${ }^{1}$, Jinhui Liu ${ }^{1}$, \\ Weidong Zhang ${ }^{1}$, Rongbin $\mathrm{Li}^{3}$, Shaojun Zhang ${ }^{1}$ and Jiang Du ${ }^{1,4, *(\mathbb{D})}$ \\ 1 Henan Province Industrial Technology Research Institute of Resources and Materials, Zhengzhou University, \\ Zhengzhou 450001, China; jiaguanwei@126.com (G.J.); 13673387324@163.com (B.L.); \\ 13592589651@163.com (K.W.); wangcd@zzu.edu.cn (C.W.); yangpx@zzu.edu.cn (P.Y.); \\ jhliu13s@alum.imr.ac.cn (J.L.); zhangwd@zzu.edu.cn (W.Z.); zhangshaojun@zzu.edu.cn (S.Z.) \\ 2 School of Physics and Electronics, Henan University, Kaifeng 475004, China \\ 3 School of metallurgical and Ecological Engineering, University of Science and Technology Beijing, \\ Beijing 100083, China; lirongbin822@163.com \\ 4 Department of Chemical Engineering, Texas Materials Institute, Center for Nano- and Molecular Science and \\ Technology, The University of Texas at Austin, Austin, TX 78712, USA \\ * Correspondence: 0210927@163.com
}

Received: 8 January 2019; Accepted: 20 February 2019; Published: 11 March 2019

check for updates

\begin{abstract}
We report on the synthesis of $\mathrm{CuInTe}_{2}$ nanoparticles and their function in photovoltaic equipment, such as solar cells. Under certain synthesis conditions, the $\mathrm{CuInTe}_{2}$ nanocrystals form shape with nanocrystals, nanorods or nanocubes. It was found that CuTe nanocrystals could be converted to $\mathrm{CuInTe} \mathrm{e}_{2}$ by addition of an In reactant. CuInTe 2 nanorods were synthesized using this method.
\end{abstract}

Keywords: $\mathrm{CuInTe}_{2}$; formation mechanism; nanocrystals; nanorods; photovoltaics

\section{Introduction}

I-III-VI 2 semiconductors have proved to be one of the highest power conversion efficiency photovoltaic materials in thin film photovoltaic applications [1-4]. In particular, cells with efficiency exceeding $20 \%$ has been produced using the $\mathrm{Cu}(\mathrm{In}, \mathrm{Ga}) \mathrm{Se}_{2}$ as a solar absorber layer [5].

Copper indium telluride $\left(\mathrm{CuInTe}_{2}\right)$ is mainly used as an important $\mathrm{I}-\mathrm{III}-\mathrm{VI}_{2}$ semiconductor, which has application in thermoelectric [6], photoluminescence [7], nanowire [8-10], and photovoltaic devices [11-15]. The direct bandgap of CuInTe $e_{2}$ is between 0.91 and $1.02 \mathrm{eV} \mathrm{[16]} \mathrm{at} \mathrm{around} 27^{\circ} \mathrm{C}$, which is slightly narrower in comparison to $\mathrm{CuInSe}_{2}$ thin film $(1.04 \mathrm{eV})$ [17]. The narrow bandgap absorber $(\mathrm{Eg}<1 \mathrm{eV})$ is required for making use of the bottom cells for multi-junction (tandem) solar cells. Meanwhile, $\mathrm{CuInTe}_{2}$ single-junction photovoltaic devices (PVs) have been made with power conversion efficiency (PCEs) of up to 5.1\% [18]. Compared to CuInS ${ }_{2}$ and CuInSe ${ }_{2}, \mathrm{CuInTe}_{2}$ provides a more significant quantum confinement effect and a greater Bohr radius, with the virtue of the covalent property of tellurium [19].

The record efficiency PV materials of $\mathrm{Cu}(\mathrm{In}, \mathrm{Ga}) \mathrm{Se}_{2}$ [5], and $\mathrm{CuInTe}_{2}$ [18] are fabricated by co-evaporation, which leads to a sharp increase of the costs. $\mathrm{Cu}(\mathrm{In}, \mathrm{Ga}) \mathrm{Se}$ (CIGS) has been fabricated as a nanoparticle dispersion solar coating that can be printed or sprayed. Therefore, it could, ideally, omit the procurement of intensive postdeposition [20]. Solar paints could adopt large and continuous roll-to-roll technology on almost all types of surfaces with moderate conditions. The CuInTe 2 nanocrystals can be obtained either with microwave irradiation [21,22], by solvothermal synthesis [23], 
or by using a silicate matrix method [19]. However, by using these methods, the CuInTe 2 was heavily aggregated and could not be well dispersed and; thus, could not be used for solar paints.

We demonstrate the potential of stearic acid to govern the fabrication of $\mathrm{CuInTe} \mathrm{T}_{2}$ nanocrystals and detail a facile synthetic approach for $\mathrm{CuInTe} \mathrm{T}_{2}$ nanocrystals. The CuInTe 2 nanocrystals are used for PVs and show preliminary efficiency. We further demonstrate the growth mechanism of CuInTe 2 nanocrystals and evolve it into a general method to directly convert $\mathrm{CuTe}$ into $\mathrm{CuInTe} 2$.

Except for the size control of $\mathrm{CuInTe}_{2}$ nanoparticles, stearic acid can also improve the dispersity of $\mathrm{CuInTe}_{2}$ nanoparticles in polar solvent and; thus, can be used for solar paints. The cation exchange routes give us a new synthetic method to synthesis $\mathrm{CuInTe}_{2}$ with a nanorod morphology, which has not been reported previously.

\section{Materials and Methods}

\subsection{Materials}

Tellurium powder (99.99\%), copper(II) acetylacetonate $\left(\mathrm{Cu}(\mathrm{acac})_{2}\right)(99.99+\%), \mathrm{CuCl}(99.99+\%)$, Indium(III) acetylacetonate $\left(\operatorname{In}(\mathrm{acac})_{3}\right)(99.99+\%)$, stearic acid $(98.5+\%)$, trioctylphosphine (TOP) (97\%), 1-octadecene (ODE) (90\%), and $\mathrm{CdSO}_{4}$ (99.999\%) were received from Aldrich Chemical Co. (Milwaukee, United States); Oleylamine (OLA) from TCI America (Portland, United States); ethanol (absolute), toluene (99.99\%), and ammonium hydroxide (18 $\mathrm{M} \mathrm{NH}_{3}$; ACS certified) from Fisher Scientific (Waltham, United States); and thiourea (>99.0\%) from Sigma-Aldrich (St. Louis, United States). Oleylamine was degassed overnight at $110^{\circ} \mathrm{C}$ under vacuum. All other chemicals were used without additional purification.

\subsection{CuInTe 2 Nanocrystals (2 mmol stearic acid) Synthesis}

In a typical synthesis, $0.5 \mathrm{mmol}$ of $\mathrm{Cu}(\text { acac })_{2}$ and $0.5 \mathrm{mmol}$ of $\mathrm{In}(\text { acac })_{3}$ were mixed with $2 \mathrm{mmol}$ stearic acid and $12 \mathrm{~mL}$ of ODE in a $25 \mathrm{~mL}$ three-neck flask. The mixture was heated under vacuum to $110{ }^{\circ} \mathrm{C}$ to obtain a clear blue solution and kept at this temperature for 30 min to remove low-boiling-point impurities. $0.5 \mathrm{mmol}$ OLA was injected into the flask and the mixture was degassed for a further $30 \mathrm{~min}$. The temperature was then increased, under nitrogen, to $170{ }^{\circ} \mathrm{C}$ and $1.0 \mathrm{~mL}$ of $1 \mathrm{M}$ TOP-Te was injected into the flask. Upon injection, the solution color immediately changed to dark brown. Just after injection, the temperature was set to $230^{\circ} \mathrm{C}$, and $\mathrm{CuInTe}$ nanocrystals were allowed to grow for $20 \mathrm{~min}$. After cooling to room temperature, centrifugation was used to wash the particles using ethanol and toluene as antisolvent and solvent, respectively. Toluene was added to reach a final nanocrystal concentration of $20 \mathrm{mg} / \mathrm{mL}$.

\subsection{CuInTe 2 Nanocrystals (4 mmol stearic acid) Synthesis}

The same procedures were carried out to get larger size CuInTe 2 nanocrystals, but stearic acid was increased from 2 to $4 \mathrm{mmol}$.

\subsection{CuTe Nanocubes Synthesis}

$1.0 \mathrm{mmol}$ of $\mathrm{CuCl}$ was mixed with $12 \mathrm{~mL}$ of OLA in a $25 \mathrm{~mL}$ flask. The mixture was heated under vacuum to $110{ }^{\circ} \mathrm{C}$ to obtain a clear solution and kept at this temperature for 30 min to remove low-boiling-point impurities. The temperature was then increased, under nitrogen, to $180{ }^{\circ} \mathrm{C}$ and $1.0 \mathrm{~mL}$ of $1 \mathrm{M}$ TOP-Te was injected into the flask. Upon injection, the solution color immediately changed to deep green. CuTe nanocubes were allowed to grow for $60 \mathrm{~min}$. After cooling to room temperature, centrifugation was used to wash the particles using ethanol and toluene as antisolvent and solvent, respectively. Toluene was added to reach a final nanocrystal concentration of $20 \mathrm{mg} / \mathrm{mL}$. 


\subsection{CuTe Nanorods Synthesis}

The same procedures were carried out to get the CuTe nanorods, but the TOP-Te injection temperature was lowered to $90^{\circ} \mathrm{C}$.

\subsection{Conversion of CuTe to $\mathrm{CuInTe}_{2}$}

$0.5 \mathrm{mmol}(0.096 \mathrm{~g})$ of CuTe (without taking the mass fraction of ligands into account) and $0.5 \mathrm{mmol}$ of $\operatorname{In}(\mathrm{acac})_{3}$ were mixed with $4 \mathrm{mmol}$ of stearic acid and $12 \mathrm{~mL}$ of ODE in a $25 \mathrm{~mL}$ three-neck flask. The mixture was heated under vacuum to $110{ }^{\circ} \mathrm{C}$ and kept at this temperature for 30 min to remove low-boiling-point impurities. $0.5 \mathrm{mmol}$ OLA was injected into the flask and the mixture was degassed for a further $30 \mathrm{~min}$. The temperature was then increased, under nitrogen, to $170{ }^{\circ} \mathrm{C}$ and $0.5 \mathrm{~mL}$ of $1 \mathrm{M}$ TOP-Te was injected into the flask. The temperature was set to $230{ }^{\circ} \mathrm{C}$, and the convert process was allowed for $20 \mathrm{~min}$. After cooling to room temperature, centrifugation was used to wash the particles using ethanol and toluene as antisolvent and solvent, respectively. Toluene was added to reach a final nanocrystal concentration of $20 \mathrm{mg} / \mathrm{mL}$.

\subsection{Materials Characterization}

Current-potential (IV) characteristics were collected using a Keithley 2400 source meter under AM 1.5G illumination (100 $\left.\mathrm{mW} / \mathrm{cm}^{2}\right)$. The National Institute of Standards and Technology (NIST) calibrated Si photodiode (Hamamatsu, S1787-08) was used to tune light intensity. External quantum efficiency (EQE) was measured as previously described [24]. Monochromatic light (Newport Cornerstone $2601 / 4 \mathrm{M}$ ) at wavelengths ranging from 300 to $1300 \mathrm{~nm}$, in $10 \mathrm{~nm}$ steps, was chopped at $213 \mathrm{~Hz}$ and focused to a 1-mm diameter spot size on the device at zero bias. EQE was measured using a lock-inamplifier (Stanford Research Systems, model SR830) after calibrating light intensity with silicon (Hamamatsu) and germanium (Judson) photodiodes.

Low-resolution transmission electron microscopy (TEM) images were acquired on a FEI Tecnai Spirit Bio Twin operated at $80 \mathrm{kV}$. High-resolution transmission microscopy (HRTEM) images were acquired on a field emission JEOL 2010F TEM operated at $200 \mathrm{kV}$. The JEOL 2010F TEM is equipped with an Oxford INCA EDS detector, which was used to collect EDS data. UV-vis-NIR absorbance spectra were acquired with a Varian Cary 500 UV-vis-NIR spectrophotometer.

X-ray diffraction (XRD) was performed using a Rigaku R-Axis Spider diffractometer with an image-plate detector and $\mathrm{Cu} K \alpha(\lambda=1.54 \AA)$ radiation operated at $40 \mathrm{kV}$ and $40 \mathrm{~mA}$, respectively. XRD samples were prepared by drying a drop of concentrated nanoparticle dispersion onto a glass slide in a glovebox. The nanocrystal powder was then suspended on a $0.5 \mathrm{~mm}$ nylon loop using mineral oil for analysis. Samples were scanned for $10 \mathrm{~min}$ while rotating at $5^{\circ} / \mathrm{s}$. The $2 \mathrm{D}$ diffraction patterns were integrated using the Rigaku 2DP powder processing suite, with subtraction of the background scattering from the nylon loop and mineral oil.

Raman spectroscopy was performed using a $514 \mathrm{~nm}$ Ar ion laser source operated at $0.5 \mathrm{~mW}$ using a Renishaw microscope system set up in reflection mode. The beam was focused through a $50 \times$ objective, making a spot size approximately $1.3 \mu \mathrm{m}$ in diameter on the sample.

\subsection{Device Fabrication}

CuInTe 2 nanocrystal PVs were fabricated with an $\mathrm{Au} / \mathrm{CuInTe} 2 / \mathrm{CdS} / \mathrm{i}-\mathrm{ZnO} /$ indium tin oxide (ITO) device structure. A $5 \mathrm{~nm}$ layer of $\mathrm{Cr}$ followed by $60 \mathrm{~nm}$ of Au were thermally deposited onto soda lime glass (Delta Technologies, $25 \times 25 \times 1.1 \mathrm{~mm}$ polished float glass). Films of CuInTe 2 nanocrystals were spray deposited from toluene at room temperature. A CdS buffer layer was deposited by dropping $0.7 \mathrm{~mL}$ of a CdS precursor solution $\left(1.25 \mathrm{~mL}\right.$ of $15 \mathrm{mM} \mathrm{CdSO}_{4}, 2.2 \mathrm{~mL}$ of $1.5 \mathrm{M}$ thiourea, and $2.8 \mathrm{~mL}$ of $18 \mathrm{M} \mathrm{NH}_{4} \mathrm{OH}$ in water) onto the $\mathrm{CuInTe} 2$ nanocrystal film, heated to $95{ }^{\circ} \mathrm{C}$ on a hot plate, and covered with an inverted crystallization dish for $2 \mathrm{~min}$. The substrate was removed from the hot plate, rinsed with deionization (DI) water, and dried with a stream of compressed air. Top 
layers of $\mathrm{i}-\mathrm{ZnO}$ and ITO were deposited by radio frequency (RF) sputtering from a $\mathrm{ZnO}$ target (Lesker, 99.9\%) in a $0.5 \% \mathrm{O}_{2}$ in Ar atmosphere (Praxair, 99.95\%) and an ITO target (Lesker, 99.99\% $\mathrm{In}_{2} \mathrm{O}_{3}: \mathrm{SnO}_{2}$ 90:10) in Ar atmosphere (Praxair, research grade). ZnO and ITO were deposited selectively onto 8 rectangular regions with active device areas of $0.08 \mathrm{~cm}^{2}$. Silver paint was applied for electrical contact to the devices.

\section{Results}

The nanocrystals were confirmed as sphalerite (cubic) CuInTe 2 through X-ray diffraction (XRD), which are shown in Figure 1. EDS from fields of the nanoparticles showed the mean $\mathrm{Cu} / \mathrm{In} / \mathrm{Te}$ composition of 0.24:0.28:0.48, which was close to the ideal target 0.25:0.25:0.50 ratio. The band gap energy was $1.0 \mathrm{eV}$ through the optical absorbance spectra of nanocrystals dispersion. And the $1.0 \mathrm{eV}$ was near to the reference value $1.02 \mathrm{eV}$ for $\mathrm{CuInTe} 2$ [6].

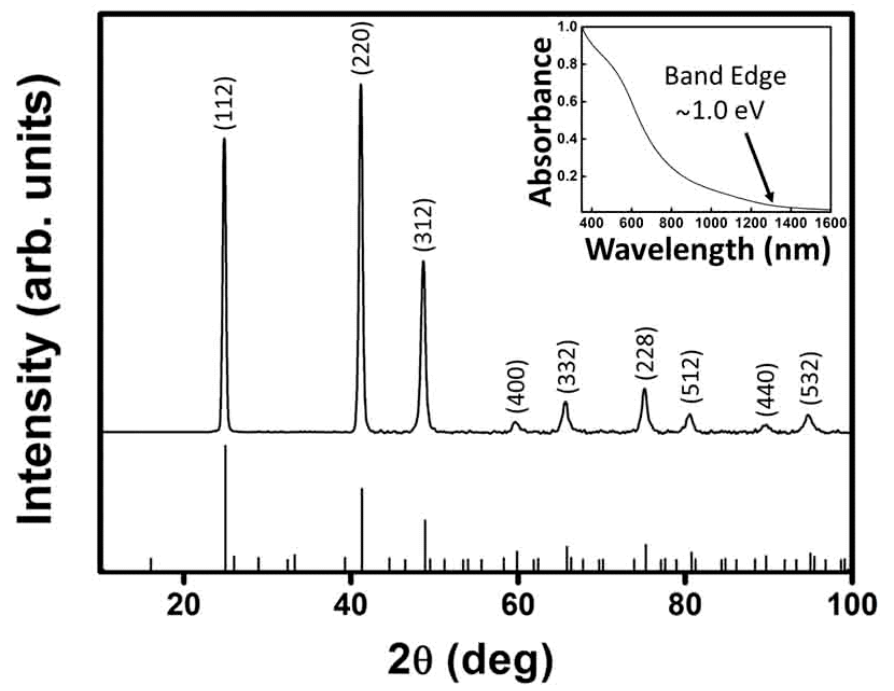

Figure 1. X-ray diffraction (XRD) of CuInTe 2 nanocrystals (2 $\mathrm{mmol}$ stearic acid). The peak labels correspond to those of sphalerite (cubic) $\mathrm{CuInTe}_{2}$ (PDF No. 43-1401). Inset: CuInTe 2 nanoparticles are dispersed in toluene and their UV-vis-near infrared absorbance spectrum is demonstrated.

TEM images of CuInTe 2 nanocrystals are revealed in Figure 2. The mean diameter of nanocrystals was $15.3 \pm 3.6 \mathrm{~nm}$, which were crystalline. Many of these $\mathrm{CuInTe} \mathrm{I}_{2}$ nanocrystals had sharp edges, which

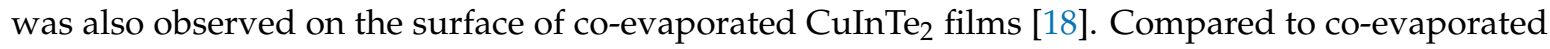
$\mathrm{CuInSe} \mathrm{f}_{2}$ films, under the same co-evaporated conditions, $\mathrm{CuInTe} \mathrm{T}_{2}$ film had larger and more faceted surface [25], which relate to the physical properties of a relatively low epitaxy reaction temperature $\left(347^{\circ} \mathrm{C}\right)$ and melting point $\left(789^{\circ} \mathrm{C}\right)$.
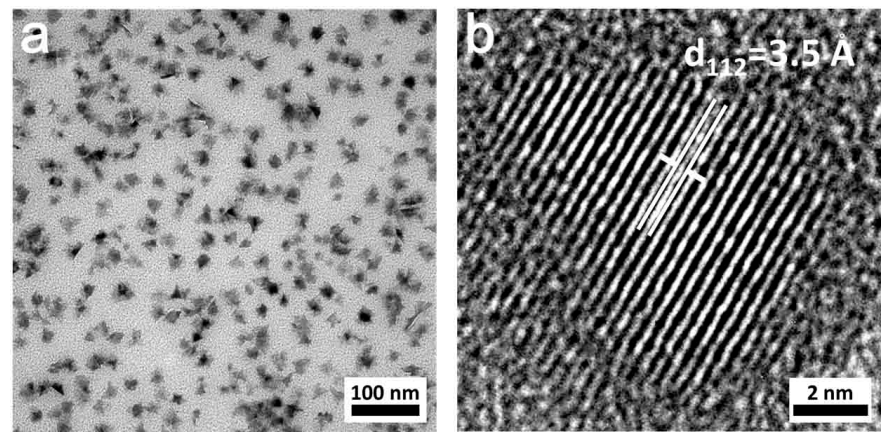

Figure 2. Transmission electron microscopy (TEM) (a) and high-resolution transmission microscopy (HRTEM) (b) of CuInTe 2 nanocrystals (2 mmol stearic acid). 
As shown in Figure 3, peaks were deconvoluted using Lorentzians. The most prominent of these peaks appeared at $131 \mathrm{~cm}^{-1}$, which we assigned to the $A_{1}$ mode of CuInTe 2 . This $A_{1}$ mode shifted to higher wavenumbers compared to the previously calculated and observed value $\left(127 \mathrm{~cm}^{-1}\right)$. [26] Similar shifts of the $\mathrm{A}_{1}$ mode have been previously studied in $\mathrm{CuInSe}_{2}$ and indicate a lack of chalcopyrite cation ordering $[27,28]$. In sphalerite $\mathrm{CuInSe}{ }_{2}$, such a shift of the $\mathrm{A}_{1}$ mode to higher wavenumbers was accompanied by the disappearance of certain XRD peaks that are characteristic of the chalcopyrite structure. Those missing peaks all have odd integers for $l$ in the Miller index ( $h k l)$ and, if present, would confirm chalcopyrite cation ordering. From Figure 3, it can be seen that the nanocrystals used in this investigation lacked diffraction peaks containing odd values of $l$. Due to the shift of the $A_{1}$ mode to higher wavenumbers and the lack of diffraction peaks containing odd $l$-values, the shalerite structure was confirmed.

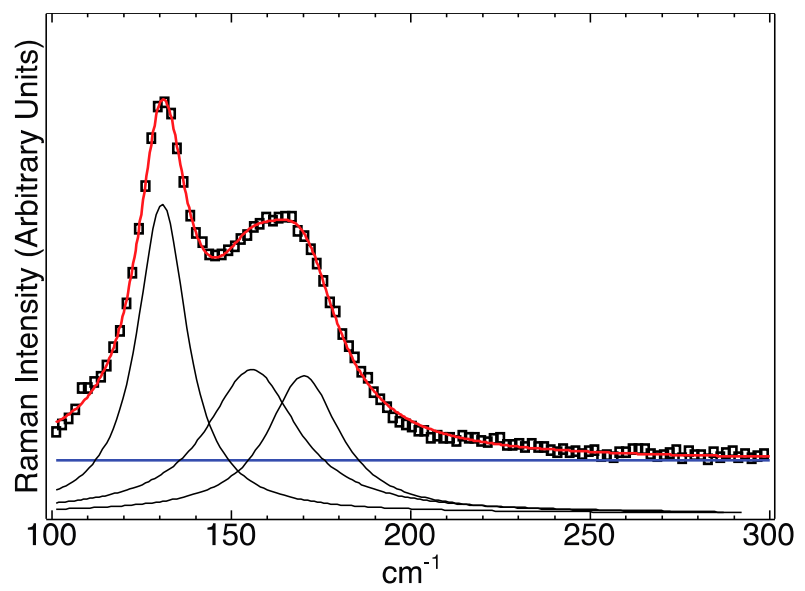

Figure 3. Deconvoluted CuInTe 2 spectrum shows peaks at 131, 156, and $170 \mathrm{~cm}^{-1}$. Black squares are actual data, and the red line is the sum of all the fitted components. The blue horizontal line is a fitted parameter to account for the background caused by ligand fluorescence.

Furthermore, the deconvoluted Raman peaks at $156 \mathrm{~cm}^{-1}$ and $170 \mathrm{~cm}^{-1}$ were in good agreement with previously observed peaks $\left(158.5 \mathrm{~cm}^{-1}\right.$ and $\left.169.9 \mathrm{~cm}^{-1}\right)$ [26], and match fairly well to the theoretically estimated $E^{2}\left(160.8 \mathrm{~cm}^{-1}\right)$ and $\mathrm{E}^{3}\left(171.5 \mathrm{~cm}^{-1}\right) \mathrm{CuInTe}$ modes [29] based on a simplified Keating model. Full Lorentzian fit parameters are found in the Table S1.

For the $\mathrm{CuInTe} 2$ nanocrystals, the size and morphology can be governed through adjusting the stearic acid/metal ratio. Figure 4 demonstrates the $\mathrm{CuInTe}_{2}$ about the morphology of nanocrystals (4 mmol stearic acid), obtained by increasing the stearic acid-metal ratio from 4:1 to 8:1. The CuInTe 2 nanocrystals ( $4 \mathrm{mmol}$ stearic acid) were crystalline (Figure $4 \mathrm{~d}$ ) and had triangle-shaped edges and bodies (Figure 4c). XRD (Figure S1) confirmed that the nanocrystals (4 mmol stearic acid) were sphalerite (cubic) $\mathrm{CuInTe}_{2}$. We assumed that stearic acid concentration dominated nanocrystals nucleation. When the concentration of stearic acid was increased, a lower nucleation rate was initially obtained, increasing the total amount of precursor for posterior nanocrystals growth. Consequently, these larger $\mathrm{CuInTe} 2$ nanocrystals ( $4 \mathrm{mmol}$ stearic acid) were ultimately obtained. Meanwhile, compared to $\mathrm{CuInSe}_{2}$ nanoparticles under similar synthetic conditions [20], the morphology of CuInTe 2 nanoparticles were more faceted. Similar results have been reported in the synthesis of CuInTe 2 and $\mathrm{CuInSe}_{2}$ thin films by the co-evaporation system under the same growth conditions. This notable morphology feature of $\mathrm{CuInTe}_{2}$-based thin films relates to the physical properties of a relatively low epitaxy temperature $\left(347^{\circ} \mathrm{C}\right)\left[30\right.$ ] and melting point $\left(789^{\circ} \mathrm{C}\right)$ [31] compared to CuInSe 2 . Models for the different crystal growth mechanisms, symmetrical polyhedrons, are presented elsewhere [32]. 

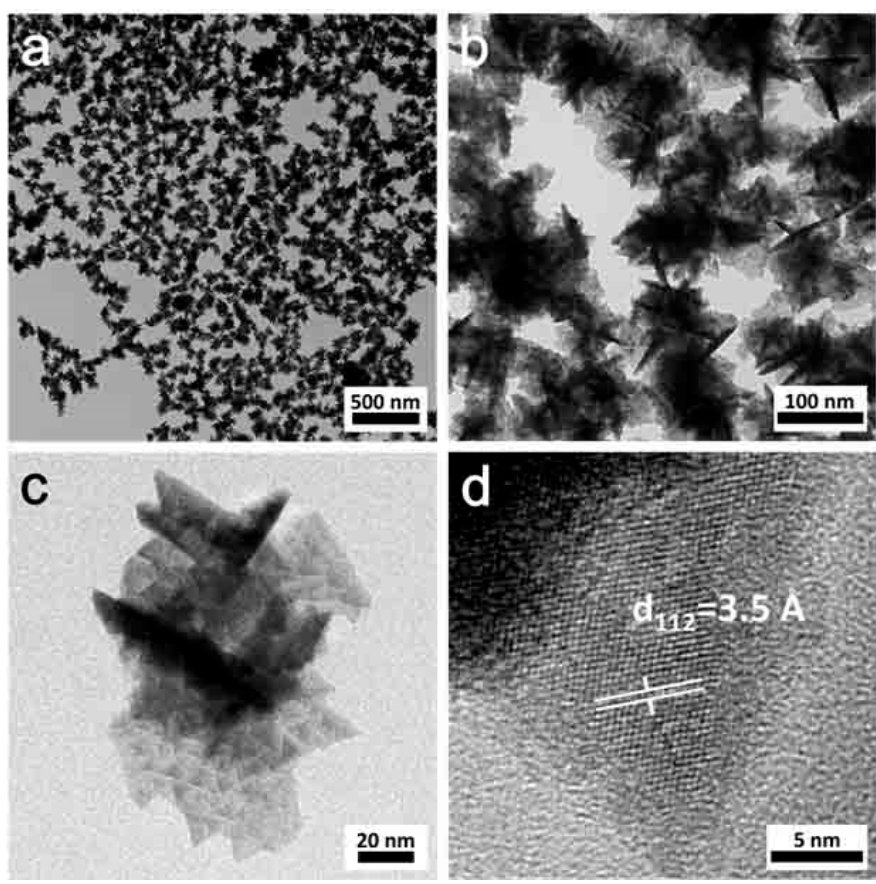

Figure 4. TEM (a-c) and HRTEM (d) of CuInTe 2 nanocrystals (4 mmol stearic acid).

The composition of the CuInTe 2 nanocrystals ( $4 \mathrm{mmol}$ stearic acid) was ascertained by the elemental maps from energy-dispersive X-ray (EDX) spectroscopy (Figure 5). EDS from the sample of the CuInTe 2 nanocrystals ( 4 mmol stearic acid) revealed a mean $\mathrm{Cu}-\mathrm{In}-\mathrm{Te}$ containment of 0.24:0.26:0.50.
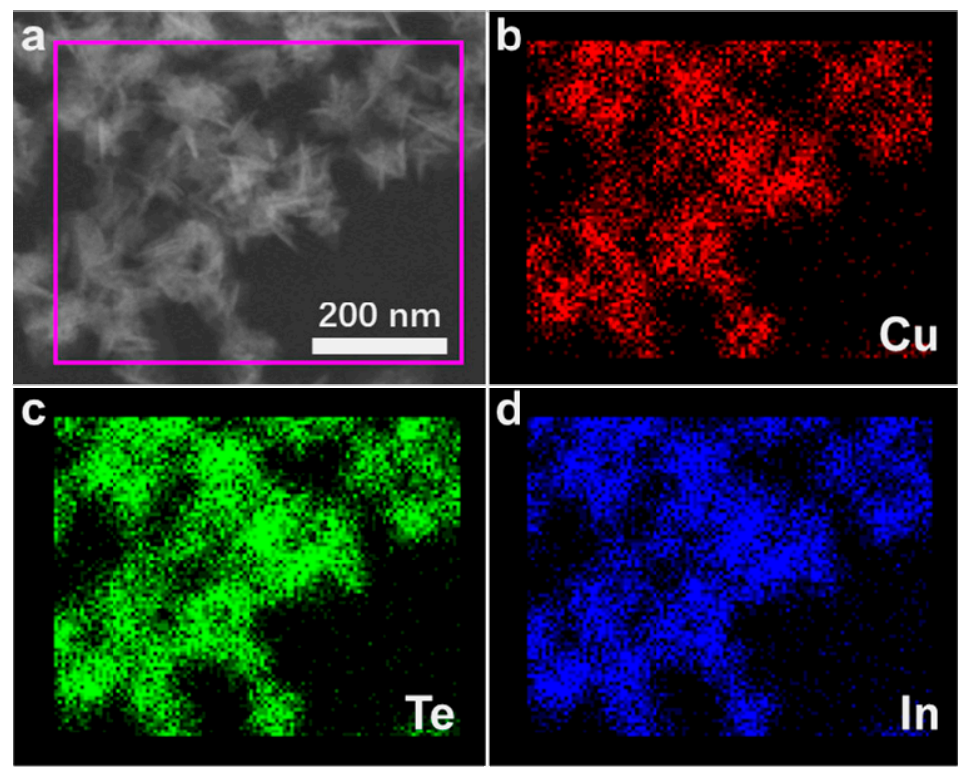

Figure 5. Scanning transmission electron microscopy (STEM) and energy-dispersive X-ray (EDX) elemental mapping of $\mathrm{Cu}$, In, and Te of $\mathrm{CuInTe}_{2}$ nanocrystals (4 mmol stearic acid).

Photovoltaic devices were fabricated by using $\mathrm{CuInTe}_{2}$ nanocrystals as the absorber layer $(2 \mathrm{mmol}$ stearic acid). Similar to CIGS, CuInTe 2 coatings were typically p-type [33], and test equipment was composed of a layered structure that consisted of $\mathrm{Au} / \mathrm{CuInTe} \mathrm{H}_{2} / \mathrm{CdS} / \mathrm{ZnO} /$ indium tin oxide (ITO). $\mathrm{CuInTe}_{2}$ nanocrystals were deposited by spray coating with a toluene dispersion. The anneal was unnecessary for the nanocrystal layer. Figure 6 (in Table S2 and Figure S6) displays the PV response of a typical device having an open-circuit voltage (VOC) of $342 \mathrm{mV}$, a short-circuit current density 
(JSC) of $10.651 \mathrm{~mA} / \mathrm{cm}^{2}$, a fill factor (FF) of 0.335 , and a power conversion efficiency (PCE) of $1.221 \%$ with the conditions AM 1.5. Compared with the previous report [12], the photovoltaic performance parameters (Voc, Jsc, and FF) were lower. The reason was that the absorber layer was not annealed or chemically treated.

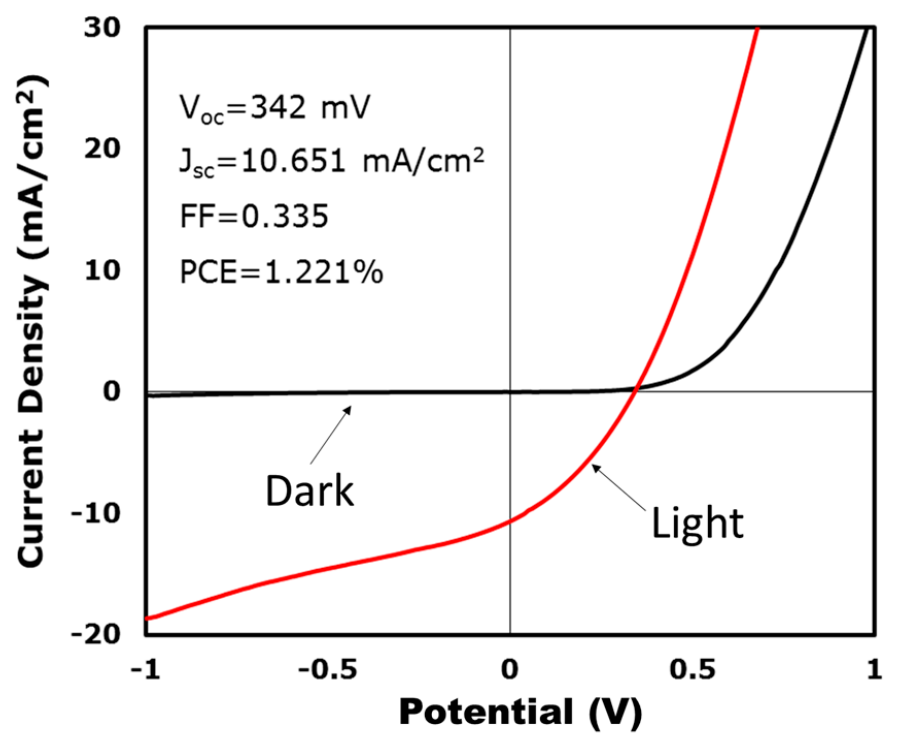

Figure 6. Current-voltage properties of a CuInTe 2 nanocrystals photovoltaic (PV) device.

The incident photon conversion efficiency (IPCE) (Figure 7) was in accordance with the absorbance spectra of the CuInTe 2 nanoparticles. Additionally, the response results were ascertained by the CuInTe 2 nanoparticles. The relatively high IPCE of $\sim 22.5 \%$, for wavelengths between 400 and $500 \mathrm{~nm}$, tailed off at higher wavelengths. The strong photovoltaic response of IPCE in the 400-500 nm region might have been due to the cadmium sulfide (CdS) layer [34-36]. The long wavelength IPCE cutoff at $\sim 1250 \mathrm{~nm}$ corresponded to the optical gap $(1.02 \mathrm{eV})$ of the $\mathrm{CuInTe} \mathrm{I}_{2}$ nanoparticles, and the sharp drop in IPCE at wavelengths $<400 \mathrm{~nm}$ was the result of $\mathrm{ZnO}$ light absorption [20].

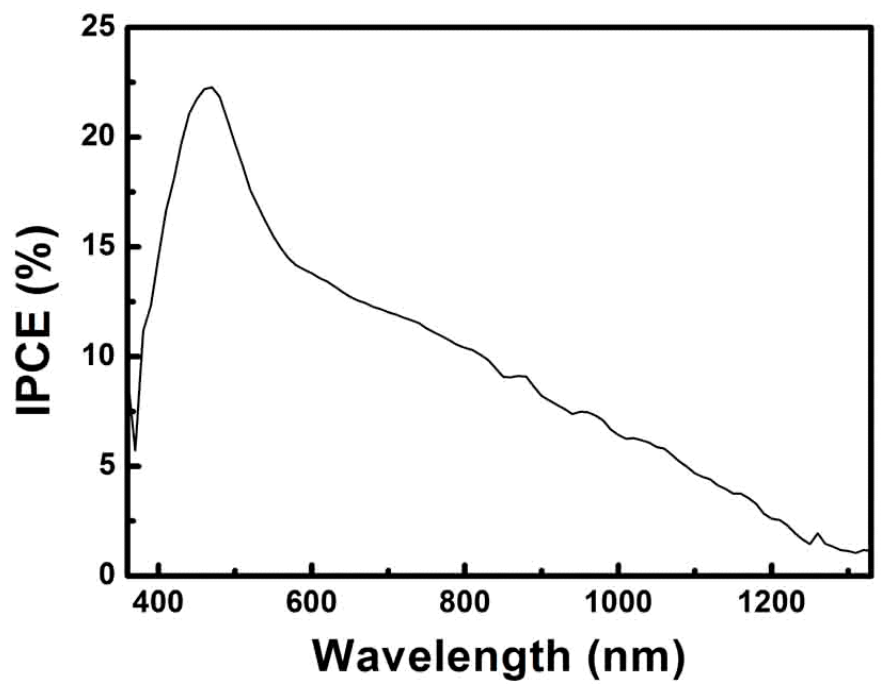

Figure 7. Incident photon conversion efficiency (IPCE) spectra of the CuInTe $\mathrm{T}_{2}$ nanocrystals PV device.

Time-chasing XRD studies of CuInTe 2 nanocrystals were carried out to obtain information on the growth mechanism of this system. XRD (Figure 8a) showed that when the reaction time was 5 min, $\mathrm{CuTe}$ nanocrystals formed as a major phase together with minor $\mathrm{CuInTe}$. The reason for CuTe forming as the major phase, formed in the initial stage of the reaction, may be due to the greater reactivity of 
the $\mathrm{Cu}$-aliphatic amines complex, compared with In-aliphatic amines complexes [37]. After $10 \mathrm{~min}$ of the reaction, $\mathrm{CuInTe} 2$ ends up being favored (Figure $8 \mathrm{~b}$ ). However, it is interesting to hypothesize CuTe being converted into CuInTe 2 as a transition according to TEM images shown in the Figure 9.

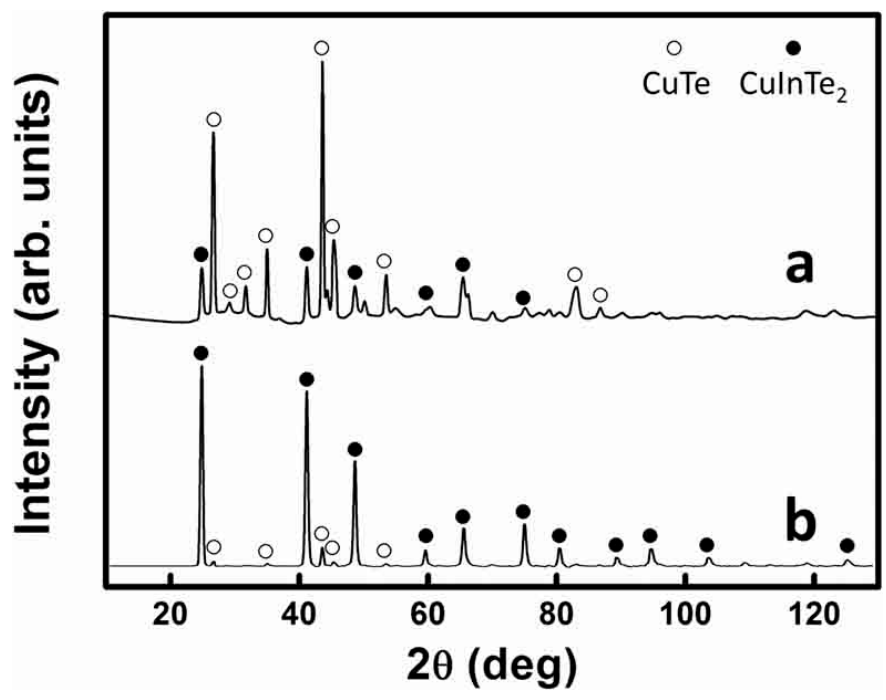

Figure 8. XRD of when the CuInTe 2 nanocrystals reaction was taken: (a) 5 min; and (b) $10 \mathrm{~min}$. (CuTe: portable document format (PDF) No. 26-0524 and CuInTe 2 : PDF No. 43-1401).

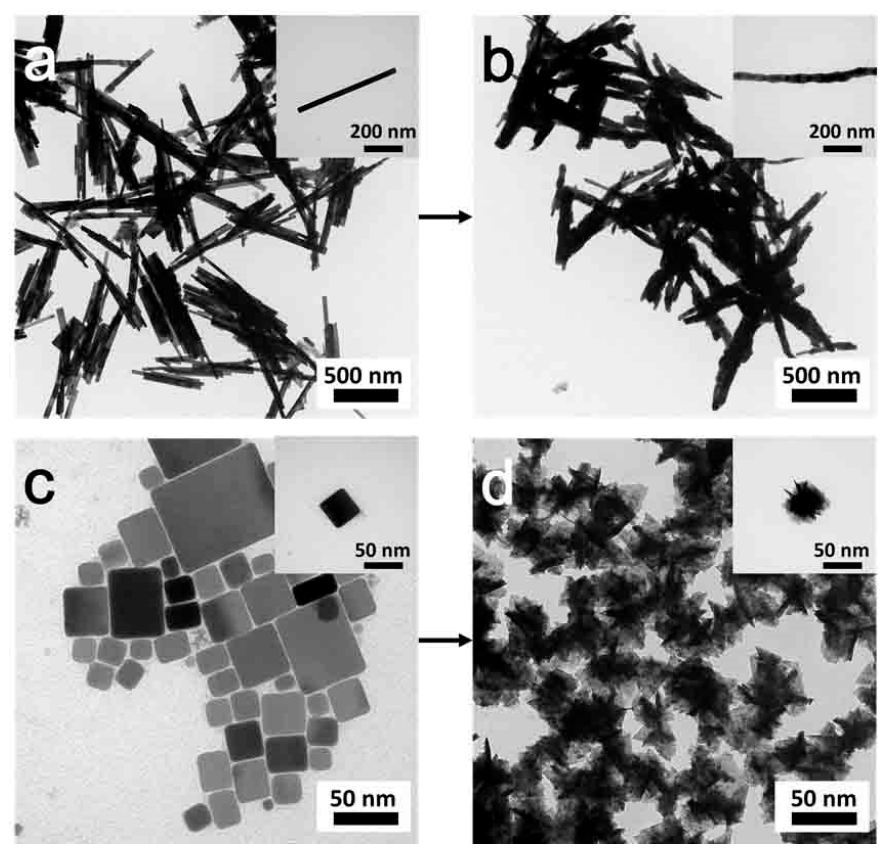

Figure 9. TEM of converting (a) CuTe nanorods into (b) CuInTe 2 nanorods, and converting (c) CuTe nanocubes into (d) $\mathrm{CuInTe}_{2}$ nanocrystals.

Following this growth mechanism hypothesis, we successfully directly converted CuTe nanorods (TEM in Figure 9a, XRD data in Figure S2a) and CuTe nanocubes (TEM in Figure 9c, XRD data in Figure S2c) into CuInTe 2 nanorods (TEM in Figure 9b, XRD data in Figure S2b, HR-TEM in Figure S5a) and CuInTe 2 nanocubes (TEM in Figure 9d, XRD data in Figure S2d, HR-TEM in Figure S5b) under the same reaction conditions (Figure S2). CuTe nanorods and nanocubes can be synthesized by varying the TOP-Te injection temperature in the OLA system (Figure 9a,c). XRD and HRTEM (Figures S2 and S5) proved the crystal phase, composition, and lattice structure of CuInTe 2 . Time-chasing XRD (Figures S3 and S4) of the converting process also confirmed that, after the reaction at $5 \mathrm{~min}, \mathrm{CuInTe}_{2}$ 
started forming. It should be a facile and general method to directly convert CuTe (with different morphologies) into CuInTe 2 .

As per the TEM (Figure 10) shown, it was the hypothesis that when the convert reaction time was $5 \mathrm{~min}$, the converting process of the $\mathrm{CuInTe} 2$ started at the two ends of the CuTe nanorods and at the surface of the CuTe nanocubes.
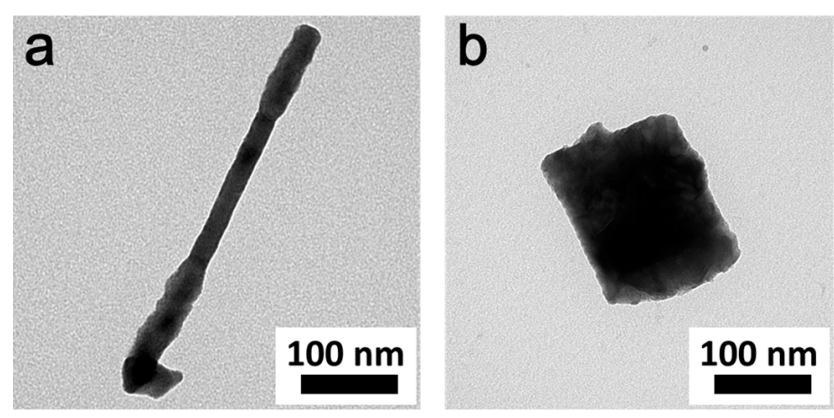

Figure 10. TEM of converting (a) CuTe nanorods and (b) CuTe nanocubes into CuInTe 2 . The reaction time was $5 \mathrm{~min}$.

\section{Conclusions}

In conclusion, a synthetic approach for obtaining $\mathrm{CuInTe}_{2}$ nanocrystals with different morphologies has been extended. The size morphology of $\mathrm{CuInTe}_{2}$ nanocrystals can be governed through adjusting the stearic acid-metal ratio. PV equipment assembled with the synthetic $\mathrm{CuInTe} 2$ nanocrystals demonstrated PCEs of increments up to 1.221\% (PCEs of all devices on the chip are shown in Table S2 and Figure S6). However, owing to the lack of the process of deposition, with any high-temperature or chemical means on the solar absorber layers, the power conversion efficiency of the devices was slightly lower. In order to improve the PV efficiency for application, the synthetic and device fabrication process should be further optimized. The formation mechanism of CuInTe 2 nanocrystals was explored and we invented a facile and general method to directly convert CuTe nanostructures into CuInTe 2 . CuInTe 2 nanorods were firstly synthesized, and it could be used for advanced nanodevices such as sensors and photodetectors, etc.

Supplementary Materials: The following are available online at http:/ www.mdpi.com/2079-4991/9/3/409/s1, Figure S1: XRD of (a) CuInTe 2 nanocrystals ( $4 \mathrm{mmol}$ stearic acid). Figure S2: XRD of converting (a) CuTe nanorods into (b) CuInTe 2 nanorods, and (c) CuTe nanocubes into (d) CuInTe 2 nanocrystals. Figure S3: XRD of converting $\mathrm{CuTe}$ nanocubes into CuInTe$e_{2}$ nanocrystals. The reaction time was $5 \mathrm{~min}$. Figure S4: XRD of converting CuTe nanorods into CuInTe 2 nanorods. The reaction time was $5 \mathrm{~min}$. Figure S5: HRTEM of (a) CuInTe $\mathrm{C}_{2}$ nanorods and (b) $\mathrm{CuInTe}_{2}$ nanocrystals. (Converted from CuTe nanorods and CuTe nanocubes). Figure S6: Current-voltage properties of a CuInTe 2 nanocrystals PV device. Table S1: Fitted Lorentzian values for Raman data. Table S2: PCEs and $I-V$ curves of all devices on the chip.

Author Contributions: Conceptualization and methodology, J.D.; writing-original draft preparation, G.J., B.L., K.W., C.W., P.Y. W.Z., and R.L; writing—review and editing, G.J., J.L., and J.D.; supervision, S.Z.

Funding: This research was funded by the National Key Research and Development Program of China (No. 2016YFB0301101), the Robert A. Welch Foundation (grant no. F-1464), the National Science Foundation through its Industry/University Cooperative Research Centers program (grant No. IIP-1134849), and CJS acknowledges funding by a National Science Foundation Graduate Research Fellowship (grant No. DGE-1110007).

Acknowledgments: The authors acknowledge Professor Liguo Wang of the Henan Province Industrial Technology Research Institute of Resources and Materials.

Conflicts of Interest: The authors declare no conflicts of interest.

\section{References}

1. Stanbery, B. Copper Indium Selenides and related materials for photovoltaic devices. Crit. Rev. Solid State 2002, 27, 73-117. [CrossRef] 
2. Cha, J.H.; Noh, S.J.; Jung, D.Y. Synthesis and nanostructures of metal selenide precursors for $\mathrm{Cu}(\mathrm{In}, \mathrm{Ga}) \mathrm{Se}_{2}$ thin-film solar cells. ChemSusChem 2015, 8, 2407-2413. [CrossRef] [PubMed]

3. Du, J.; Lai, X.Y.; Halpert, J.E.; Yu, Y.; Wang, D. Formation of efficient dye-sensitized solar cells by introducing an interfacial layer of hierarchically ordered macro-mesoporous $\mathrm{TiO}_{2}$ film. Sci. China Chem. 2011, 54, 930-935. [CrossRef]

4. Zhang, X.; Yang, L.; Guo, Z.; Su, G.; Gao, R.; Wang, W.; Dong, B.; Cao, L. Rapid synthesis of CuInTe 2 ultrathin nanoplates with enhanced photoelectrochemical properties. Chem. Commun. 2017, 53, 5878-5881. [CrossRef] [PubMed]

5. Jackson, P.; Hariskos, D.; Lotter, E.; Paetel, S.; Wuerz, R.; Menner, R.; Wischmann, W.; Powalla, M. New world record efficiency for $\mathrm{Cu}(\mathrm{In}, \mathrm{Ga}) \mathrm{Se}_{2}$ thin-film solar cells beyond $20 \%$. Prog. Photovolt. Res. Appl. 2011, 19, 894-897. [CrossRef]

6. Liu, R.; Xi, L.; Liu, H.; Shi, X.; Zhang, W.; Chen, L. Ternary compound CuInTe 2 : A promising thermoelectric material with diamond-like structure. Chem. Commun. 2012, 48, 3818-3820. [CrossRef] [PubMed]

7. Rincón, C.; Wasim, S.M.; MaríN, G.; Pérez, G.S.; Bacquet, G. Temperature dependence of the photoluminescence spectra of single crystals of CuInTe. J. Appl. Phys. 1997, 82, 4500-4503. [CrossRef]

8. Jia, G.; Du, J. Foreign metal ions to control the morphology of solution-liquid-solid reaction. Cryst. Growth Des. 2018, 18, 7489-7495. [CrossRef]

9. Jia, G.; Du, J. Solution-liquid-solid growth of $\mathrm{CuInTe}_{2}$ and CuInSexTe $\mathrm{C}_{2-x}$ semiconductor nanowires. Inorg. Chem. 2018, 57, 14961-14966. [CrossRef] [PubMed]

10. Jia, G.; Du, J. Catalyst-assisted solution-liquid-solid synthesis of CdS/CuInSe 2 and CuInTe $2 / \mathrm{CuInSe}_{2}$ nanorod heterostructures. Inorg. Chem. 2019, 58, 695-702. [CrossRef] [PubMed]

11. Mise, T.; Nakada, T. Microstructural and optical properties of $\mathrm{CuIn}_{3} \mathrm{Te}_{5}$ thin films for solar cells. Sol. Energy Mater. Sol. Cells 2010, 94, 1132-1136. [CrossRef]

12. Kim, S.; Kang, M.; Kim, S.; Heo, J.H.; Noh, J.H.; Im, S.H.; Seok, S.I.; Kim, S.W. Fabrication of CuInTe 2 and $\mathrm{CuInTe}_{(2-\mathrm{x})} \mathrm{Se}_{(\mathrm{x})}$ ternary gradient quantum dots and their application to solar cells. ACS Nano 2013, 7, 4756-4763. [CrossRef] [PubMed]

13. Lakhe, M.; Chaure, N.B. Characterization of electrochemically deposited CuInTe 2 thin films for solar cell applications. Sol. Energy Mater. Sol. Cells 2014, 123, 122-129. [CrossRef]

14. Shen, H.; Duong, T.; Peng, J.; Jacobs, D.; Wu, N.; Gong, J.; Wu, Y.; Karuturi, S.K.; Xiao, F.; Weber, K. Mechanically-stacked perovskite/CIGS Tandem solar cells with efficiency of $23.9 \%$ and reduced oxygen sensitivity. Energy Environ. Sci. 2018, 11, 394-406. [CrossRef]

15. Du, J.; Jian, Q.; Wang, D.; Tang, Z. Facile synthesis of $\mathrm{Au} @ \mathrm{TiO}_{2}$ core-shell hollow spheres for dye-sensitized solar cells with remarkably improved efficiency. Energy Environ. Sci. 2012, 5, 6914-6918. [CrossRef]

16. Roy, S.; Guha, P.; Chaudhuri, S.; Pal, A.K. CuInTe 2 thin films synthesized by graphite box annealing of In/Cu/Te stacked elemental layers. Vacuum 2002, 65, 27-37. [CrossRef]

17. Kazmerski, L.L.; Shieh, C.C. Photoconductivity effects in $\mathrm{CuInS}_{2}, \mathrm{CuInSe}_{2}$ and CuInTe 2 thin films. Thin Solid Films 1977, 41, 35-41. [CrossRef]

18. Mise, T.; Nakada, T. Low temperature growth and properties of Cu-In-Te based thin films for narrow bandgap solar cells. Thin Solid Films 2010, 518, 5604-5609. [CrossRef]

19. Bodnar', I.V.; Gurin, V.S.; Solovel̆, N.P.; Molochko, A.P. Formation and optical properties of CuInTe 2 nanoparticles in silicate matrices. Semiconductors 2007, 41, 939-945. [CrossRef]

20. Panthani, M.G.; Akhavan, V.; Goodfellow, B.; Schmidtke, J.P.; Dunn, L.; Dodabalapur, A.; Barbara, P.F.; Korgel, B.A. Synthesis of CuInS, CuInSe, and $\mathrm{Cu}(\mathrm{InGa}) \mathrm{Se}$ (CIGS) nanocrystal "inks" for printable photovoltaics. J. Am. Chem. Soc. 2008, 130, 16700-16777. [CrossRef] [PubMed]

21. Grisaru, H.; Palchik, O.; Gedanken, A.; Palchik, V.; Slifkin, M.A.; Weiss, A.M. Microwave-Assisted polyol synthesis of $\mathrm{CuInTe}_{2}$ and CuInSe 2 nanoparticles. Inorg. Chem. 2003, 42, 7148-7155. [CrossRef] [PubMed]

22. Yarema, O.; Yarema, M.; Lin, W.M.; Wood, V. Cu-In-Te and Ag-In-Te colloidal nanocrystals with tunable composition and size. Chem. Commun. 2016, 52, 10878-10881. [CrossRef] [PubMed]

23. Kim, C.; Dong, H.K.; Son, Y.S.; Kim, H.; Bae, J.Y.; Han, Y.S. Solvothermal synthesis and characterization of a CuInTe 2 absorber for thin-film photovoltaics. Mater. Res. Bull. 2012, 47, 4054-4058. [CrossRef]

24. Steinhagen, C.; Akhavan, V.A.; Goodfellow, B.W.; Panthani, M.G.; Harris, J.T.; Holmberg, V.C.; Korgel, B.A. Solution-liquid-solid synthesis of $\mathrm{CuInSe}_{2}$ nanowires and their implementation in photovoltaic devices. ACS Appl. Mater. Interfaces 2011, 3, 1781-1785. [CrossRef] [PubMed] 
25. Nadenau, V.; Walter, T.; Schock, H.W. Growth of CuInTe 2 polycrystalline thin films. J. Cryst. Growth 1995, 146, 251-255. [CrossRef]

26. Ananthan, M.R.; Mohanty, B.C.; Kasiviswanathan, S. Micro-Raman spectroscopy studies of bulk and thin films of CuInTe 2 . Semicond. Sci. Technol. 2009, 24, 230-278. [CrossRef]

27. Stanbery, B.J.; Kincal, S.; Kim, W.K.; Chang, C.H.; Ahrenkiel, S.P.; Lippold, G.; Neumann, H.; Anderson, T.J.; Crisalle, O.D. Epitaxial growth and characterization of CuInSe crystallographic polytypes. J. Appl. Phys. 2002, 91, 3598-3604. [CrossRef]

28. Shirakata, S.; Murakami, T.; Kariya, T.; Isomura, S. Preparation of CuInSe 2 thin films by chemical spray pyrolysis. Jpn. J. Appl. Phys. 1996, 35, 191-199. [CrossRef]

29. Neumann, H. Lattice vibrations in AIBIIICVI2 chalcopyrite compounds. Helvetica Phys. Acta 1985, 58, 337-346.

30. Neumann, H.; Nowak, E.; Schumann, B.; Tempel, A.; Kuhn, G. Epitaxial layers of CuInTe 2 on GaAs. Cryst. Res. Technol. 1980, 15, 61-69. [CrossRef]

31. Palatnik, L.S.; Rogacheva, E.I. Phase diagrams and structure of some semiconductor $\mathrm{A}_{2}{ }^{\mathrm{I}} \mathrm{CI}_{-\mathrm{B}_{2}}^{\mathrm{III}} \mathrm{C}^{\mathrm{VI}}$ alloys. Sov. Phys. Dokl. 1967, 12, 503-506.

32. Klenk, R.; Walter, T.; Schock, H.W.; Cahen, D. A model for the successful growth of polycrystalline films of $\mathrm{CuInSe}_{2}$ by multisource physical vacuum evaporation. Adv. Mater. 1993, 5, 114-119. [CrossRef]

33. Zhang, S.B.; Wei, S.H.; Zunger, A. A phenomenological model for systematization and prediction of doping limits in II-VI and I-III-VI 2 compounds. J. Appl. Phys. 1998, 83, 3192-3196. [CrossRef]

34. Nakamura, K.; Gotoh, M.; Fujihara, T.; Toyama, T.; Okamoto, H. Influence of CdS window layer on 2- $\mu \mathrm{m}$ thick CdS/CdTe thin film solar cells. Sol. Energy Mater. Sol. Cell 2003, 75, 185-192. [CrossRef]

35. Neuschitzer, M.; Sanchez, Y.; López-Marino, S.; Xie, H.; Fairbrother, A.; Placidi, M.; Saucedo, E. Optimization of CdS buffer layer for high-performance $\mathrm{Cu}_{2} \mathrm{ZnSnSe}_{4}$ solar cells and the effects of light soaking: Elimination of crossover and red kink. Prog. Photovolt. Res. Appl. 2015, 23, 1660-1667. [CrossRef]

36. Ericson, T.; Scragg, J.J.; Hultqvist, A.; Watjen, J.T.; Szaniawski, P.; Torndahl, T.; Platzer-Bjorkman, C. Zn(O, S) Buffer Layers and Thickness Variations of CdS Buffer for $\mathrm{Cu}_{2} \mathrm{ZnSnS}_{4}$ Solar Cells. IEEE J. Photovolt. 2014, 4, 465-469. [CrossRef]

37. Wilkins, R.G.; Burkin, A.R. Complexes between metal salts and long-chain aliphatic amines. Part II. The complexes of cuprous halides with long-chain aliphatic amines. J. Chem. Soc. 1950, 27, 127-132. [CrossRef] 